\title{
THE LEGAL FRAMEWORK OF MEDIATION IN BRAZILIAN LAW ${ }^{1}$
}

Humberto Dalla Bernardina de Pinho

Associate Professor of Civil Procedural Law at UERJ. Assistant Professor of Civil Procedural Law at UNESA. Public Prosecutor for the State of Rio de Janeiro. Member of I.B.D.P. and I.I.D.P. Member of the Commissions set up by the Ministry of Justice (PLS 434/13) and by Senator Ricardo Ferraço (PLS 517/11) to prepare the Bill of the Mediation Law in Brazil. www.humbertodalla.pro.br. facebook.com/humberto.dalla.

\begin{abstract}
The text ${ }^{2}$ analyzes the introduction and evolution of the legislative treatment given to the institute of mediation in Brazilian law, from Bill No. 4,827/98 up to the Bills of the Ministry of Justice (ENAM) and the Federal Senate. Along the way we also examine the text of the Project for a new CPC (Code of Civil Procedure) and Resolution No. $125 / 10$ from the National Council of Justice. At the end the principal aspects and trends for our legal system are set out.
\end{abstract}

Keywords: Mediation - Bill - New CPC - Evolution.

\section{A HISTORICAL SKETCH: FROM BILL 4827 TO CNJ RESOLUTION 125}

In Brazil, starting from the 1990's, interest began to grow concerning the institute of mediation, especially under the influence of the Argentinean legislation enacted in $1995^{3}$.

Over here, the first lawmaking initiative took shape with Bill No. 4,827/98, arising from a proposal by Congresswoman Zulaiê Cobra, and the initial draft submitted to the House contained a concise text, setting out the definition of mediation and listing some pertinent provisions.

In the House of Representatives, as far back as 2002, the bill

1 Text updated to December 2013, taking into consideration the available version of Senate Bill 517/11, and House Bills 94/02 (mediation) and 8046/10 (new Code of Civil Procedure).

2 Many thanks to Mariana Souza and to Paul Mason for their valuable comments and suggestions to this paper.

3 PINHO, Humberto Dalla Bernardina de [organizer]. Teoria Geral da Mediação à luz do Projeto de Lei e do Direito Comparado, Rio de Janeiro: Lumen Juris, 2008. 
was approved by the Commission for the Constitution and Justice and sent to the Federal Senate, where it was given the number PLC 94, of 2002 .

However, the Federal Government, as part of the "Republican Package" that followed Constitutional Amendment No. 45, dated December 08, 2004 (known as the "Judiciary Reform"), presented various Bills modifying the Code of Civil Procedure, which led to a new report for PLC94.

The Substitute (Amendment No. 1-CCJ) was approved, which impaired the initial bill. The substitute was sent to the House of Representatives on July 11, 2006. On August 01 the bill was forwarded to the CCJC, which received it on August 07,. After that, there were no further news of it until mid-2013, when it was once again addressed, probably inspired by the bills already under discussion before the Senate.

The Bill, in its latest version, right away in art. 1 proposed regulating mediation for civil procedural matters, which might take on the following features: a) prior; b) incidental; c) judicial; and d) out-ofcourt.

Prior mediation could be either judicial or out-of-court (art. 29). In the case of judicial mediation, a request for it would interrupt the statute of limitations and should be completed within a maximum period of 90 days.

Incidental mediation (art. 34), on the other hand, would be obligatory as a rule, in the fact-finding procedure, except in cases of: a) injunctions; b) when the plaintiff or defendant is a public-law entity and the controversy involves inalienable rights (direitos indisponiveis); c) in bankruptcy, judicial recovery and civil insolvency; d) in wills and estate proceedings; e) in writs of entry, claims and adverse possession of real estate; f) in lawsuits for rectification of a public record; g) when the plaintiff opts for the procedure of a special court or arbitration; i) when no agreement was reached in prior mediation held within one hundred and eighty days before bringing the suit.

Mediation should be held within a maximum of ninety days, and if no agreement is reached, the proceeding continues. Thus, mere distribution of the initial petition to the court would interrupt the statute of limitations, would induce lis pendens and produce the other effects set forth in art. 263 of the Civil Procedure Code.

Moreover, if a writ were applied for, mediation would only proceed following examination of this issue by the judge, although the lodging of an appeal against the provisional decision would not harm the process of mediation.

In 2010 the National Council of Justice published Resolution No. 125, based on the premise of the right of access to Justice, laid 
down in art. 5, XXXV, of the Federal Constitution.

Art. 1 of the Resolution institutes the National Judiciary Policy for handling conflicts of interests, seeking to ensure everyone with the right to resolve disputes by suitable means, making it quite clear that it falls to the Judiciary Branch-not only via a resolution awarded by judicial decision - to afford other mechanisms for the resolution of conflicts, in particular the so-called consensual means, such as mediation and conciliation, while also providing the citizens with attention and guidance.

To achieve these targets, the Courts were to set up Permanent Centers for Consensual Methods of Resolution of Disputes, and install Judiciary Centers for Resolution of Disputes and Citizenship.

The Resolution also addresses qualification of the conciliators and mediators, the registry and statistical monitoring of their activities and management of the Centers ${ }^{4}$.

\section{THE PROJECT FOR THE NEW CODE OF CIVIL PROCEDURE}

In 2009 a Commission of Jurists was set up, chaired by Justice Luiz Fux, with the aim of presenting a new Code of Civil Procedure.

In record time a Preliminary Bill was presented, converted into a Legislative Bill (No. 166/10), submitted to discussion and examination by a Commission especially constituted by Senators, within the realm of the Federal Senate Commission for the Constitution and Justice.

In December 2010 a Substitute was presented by Senator Valter Pereira, which was approved by the Plenary Session of the Senate with two minor changes. The text was then sent on to the House of Representatives, where it was identified as Bill No. 8046/105.

Early 2011 saw the first initiatives of reflection on the text of the new CPC, broadening the debate with civil society and the juridical milieu, with activities held jointly by the Commission, the House of Representatives and the Ministry of Justice.

In August, a special commission was created to examine the text, chaired by Congressman Fabio Trad.

In the year 2013, under the chairmanship of Congressman Paulo Teixeira, a Substitute was presented in the month of July and an Overall Cumulative Amendment in October. At the moment that this text is being concluded, the activities of revising the text have still to be completed.

4 PELUSO, Antonio Cezar. RICHA, Morgana de Almeida [coordinators]. Conciliação e Mediação: estruturação da política judiciaria nacional, Rio de Janeiro: Forense, 2011.

5 All the steps of handling the Project for the New CPC can be followed on our blog: http:// humbertodalla.blogspot.com and at http://www.facebook.com/humberto.dalla. 
In the wording at present available of the Project for a new $\mathrm{CPC}$, we can identify the Commission's concerns with the institution of conciliation and mediation, specifically in articles 166 to 176.

The Project shows special concern with the activity of mediation done within the structure of the Judiciary Branch, although it does not rule out prior mediation or even the possibility of using other means of dispute resolution (art. 176).

In the version initially presented in the House, the fundamental principles of conciliation and mediation were safeguarded, to wit: (i) independence; (ii) neutrality; (iii) autonomy of will; (iv) confidentiality; (v) oral expression; and (vi) informality. In the October, 2013 version (Overall Cumulative Amendment), such principles were omitted.

It is important to stress the relevance of the activity to be conducted by a professional mediator. In other words, the function of mediating should not, as a rule, be accumulated with other professions, such as judges, public defenders and prosecutors.

In art. $166,3^{\text {rd }}$ and $4^{\text {th }}$ paragraphs, the Commission of Jurists, after noting that conciliation and mediation must be stimulated by all the players in the process, established an objective distinction between these two mechanisms. The differentiation comes about through the posture of the third party and the type of dispute.

Thus, the conciliator may suggest resolutions for the dispute, whereas the mediator assists the persons in conflict to identify, by themselves, alternatives of mutual benefit. Conciliation is the best suited tool for disputes involving material interests, whereas mediation is recommended in cases where it is sought to preserve or restore ties.

It is important to note that the original version of PLS 166/10 required the mediator to be registered as a member of the OAB (Brazilian Bar Association). The Report and Substitute presented on November 24, 2010 prioritized the understanding that any professional can exercise the functions of mediator.

There will be a judicial record with information on the mediator's performance, indicating, for example, the number of cases in which he/she took part, the success or failure of the activity and the issue involved in the dispute. This data will be published periodically and systematized for statistical purposes (art. 168 of the Project).

The Commission, using some of the provisions already present in the Bill of the Mediation Law, was also concerned with the ethical aspects of the mediators and conciliators, and in this regard made provision for the hypotheses of exclusion of names from the Court's recordand providing for the opening of an administrative procedure to investigate the conduct (art. 174).

As to remuneration, art. 170 of the Bill states that a table of fees will be published by the National Council of Justice $(\mathrm{CNJ})$. 
As we see, the concern of the Commission is with judicial mediation. The Bill does not forbid prior or out-of-court mediation, but merely opts not to regulate it, making it clear that interested parties may make use of this modality, resorting to the professionals available on the market.

\section{THE BILLS OF THE MINISTRY OF JUSTICE AND THE FEDERAL SENATE}

With the advent of the Project for the Code of Civil Procedure, in the year 2011 Senator Ricardo Ferraço presented to the Senate Legislative Bill 517/11, proposing the regulation of judicial and out-ofcourt mediation, so as to create a system aligned with both the future CPC and with CNJ Resolution No. 125.

In 2013 two more legislative initiatives were attached to PLS 517: PLS 405/13, the outcome of the work performed by the Commission instituted by the Senate, and chaired by Justice Luis Felipe Salomão, of the Superior Court of Justice (STJ), and PLS 434/13, result of the works of the Commission instituted by the CNJ and the Ministry of Justice, chaired by Justices Nancy Andrighi and Marco Buzzi, both of the STJ, and by the Secretary of Judiciary Reform at the Ministry of Justice, Flavio Croce Caetano.

We shall first address the text of PLS 517.

With CNJ Resolution 125 already in effect, faced with the prospects of regulation of judicial mediation by the new CPC, and given the need to deal with issues concerning the integration between adjudication and self-composing forms, in August 2011 we had the opportunity to submit suggestions to Senator Ricardo Ferraço, then involved with the works of the third edition of the Republican Pact.

We made up a working group alongside Professors Tricia Navarro and Gabriela Asmar and devoted ourselves to the task of drafting a new Preliminary Bill for a Law of Civil Mediation. After examination by the Senate Consultancy, the Senate Bill was presented, taking the number $517^{6}$, and which is now following the legislative procedure in the Federal Senate.

The Bill works with concepts more updated and adapted to Brazilian reality. For example, in art. 2 it states that "mediation is a decision-making process conducted by an impartial third party, with the aim of assisting the parties to identify or develop consensual resolutions".

With regard to modalities, art. 5 admits prior and judicial mediation, which in both cases may, chronologically, be prior, incidental

6 The text can be consulted on the Federal Senate site, at: http://www.senado.gov.br. 
or even subsequent to the procedural relationship.

Also according to the text of the Bill, the judge must "recommend judicial mediation, preferably, in disputes in which it is necessary to preserve or make good an interpersonal or social relationship, or when the decisions of the parties entail material consequences for third parties" (art. 8).

On the other hand, if mediation should prove unsuitable for resolving that dispute, the occasion may be transformed into a hearing for conciliation, provided that all of the involved parties agree to it (art. 13).

In closing, without going into the specific questions of the Bill, it is important to stress the intent of making the provisions of the new CPC and CNJ Resolution No. 125uniform and compatible, regulating the points that still lacked legal treatment.

Early 2013 also saw the constitution of a commission chaired by Justice Luis Felipe Salomão, a member of the Higher Court of Justice, with the aim of presenting the preliminary bill for the New Law of Arbitration and Mediation ${ }^{7}$.

This Bill was given number 405/13 and addresses only out-ofcourt face-to-face and electronic mediation (on-line mediation).

In the text, mediation is defined in art. 1, sole paragraph, as

"the technical activity performed by an impartial third party, with no decision-making power, who, chosen or accepted by the interested parties, hears them and encourages them, without imposing resolutions, seeking to allow them to prevent or resolve disputes by consensual means".

Art. 2 states that any issue that admits a settlement may be the subject to mediation. However, agreements that involve inalienable rights must be addressed in judicial ratification, and if interests of incapable parties are involved, the Public Prosecutor's Office must be consulted before judicial ratification.

Art. 15 determines that mediation is deemed to be instituted on the date in which the initial terms of mediation are signed, while art. 5 states that "the parties interested in submitting the solution of their dispute to mediation shall sign terms of mediation document, in writing, once the conflict has arisen, even if mediation was provided for in a contractual clause.

The final terms of mediation - signed by the parties, their attorneys and the mediator - constitutes an out-of-court title to execution,

7 http://www12.senado.gov.br/noticias/materias/2013/04/03/comissao-de-juristas-apresentaraproposta-de-modernizacao-da-lei-de-arbitragem-em-seis-meses. Consulted on April 202013. 
irrespective of the signature of witnesses (arts. 22 and 23); the parties may request judicial ratification of the final terms of mediation, so as to constitute an out-of-court title to execution.

Lastly, art. 21 authorizes holding mediation via the internet or other form of remote communication.

In May 2013, the Ministry of Justice, through the Secretariat of Judiciary Reform, in partnership with the National Council of Justice, set up a commission of specialists to submit a preliminary bill on judicial, out-of-court, public and on-line mediation ${ }^{8}$.

In its art. 3, the text determines that any issue that addresses available rights or inalienable rights that are subject to a settlement may be the subject tomediation. If the agreements address inalienable rights, they will only be valid after consulting with the Public Prosecutors and going through judicial ratification.

On the other hand, there will be no judicial mediation in cases of: a) filiation, adoption, paternal power, and annulment of matrimony; b) restraint; c) judicial recovery and bankruptcy; and d) injunctive relief. This is, somehow, a consequence of the system adopted by art. 26, "the initial petition will be distributed simultaneously to the court and the mediator, stopping the counting of the statute of limitations and lapse".

As to out-of-court mediation, art. 19 determines that the parties interested in submitting their disputes to mediation are to sign initial terms of mediation, in writing, once the dispute has arisen, even if mediation was provided for in a contractual clause. Also, art 25 states that the final terms of mediation enjoy the nature of an out-of-court title to execution and, once ratified in court, they become a judicial title to enforcement, similar to a final judgment in a court case.

With regard to public mediation, art. 33 authorizes the agencies of the direct and indirect Public Administration of the Federal Union, the States, Federal District and Municipalities, and also the Public Prosecutor's Office and Public Defender's Department, to submit disputes to which they are parties to public mediation.

Thus, public mediation may take place in disputes involving: a) public entities ; b) public entities and a private party; c) homogeneous individual, collective or diffused rights.

Lastly, on-line mediation, as set forth in art. 36, may be used as a means for resolution of conflicts in cases of sales of goods or provision of services via the internet, with the aim of resolving any domestic consumer disputes .

In November 2013, public hearings were scheduled to discuss the three bills and go into the controversial issues that still surround the

8 http://www2.camara.leg.br/camaranoticias/radio/materias/ULTIMAS-NOTICIAS/441916GRUPO-DE-JURISTAS-VAI-PROPOR-MARCO-LEGAL-DA-MEDIACAO-ECONCILIACAO-NO-BRASIL.html 
theme. The Reporter for the subject in the Senate, Senator Vital do Rego, presented a substitute for PLS 517/11, seeking to bring together what is best in the three initiatives. Then, two amendments were presented by Senator Pedro Taques and three by Senator Gim Agnello. The first amendment from Senator Taques was accepted in full, and the second, partially. The three amendments presented by Senator Agnello were rejected ${ }^{9}$.

Thus, the final text that was approved and now goes to the House of Representatives is as follows:

AMENDMENT No. - CCJ (SUBSTITUTE) SENATE LEGISLATIVE BILL No. 517, OF 2011

Addresses mediation between private parties as an alternative resolution of controversies and the settlement of disputes within the realm of the Public Administration.

The NATIONAL CONGRESS decrees:

Art. 1. ThisLawaddressesmediationas analternative means for resolution of controversies between private parties and the settlement of disputes within the realm of the Public Administration.

$1^{\text {st }}$ Paragraph - Mediation is considered to be the technical activity exercised by an impartial third party, with no decision-making power, who, chosen or accepted by the parties, assists them and stimulates them to identify or develop consensual resolutions for the controversy.

$2^{\text {nd }}$ Paragraph - Mediation is applied for the consensual resolution of disputes involving natural persons or private-law legal entities, as set forth in Chapter I of this Law.

$3^{\text {rd }}$ Paragraph - Settlement of a conflict in which at least one party is a public-law legal entity will follow the regulations established in Chapter II of this Law.

9 http://www12.senado.gov.br/noticias/materias/2013/12/11/projeto-que-disciplina-amediacao-judicial-e-extrajudicial-e-aprovado-pela-ccj. 
Chapter I-Mediation

Section I - General Provisions

Art. 2. Mediation will be oriented by the following principles:

I-impartiality of the mediator;

II - isonomy between the parties;

III - oral expression;

IV-informality;

$V$-autonomy of will of the parties;

VI-search for consensus;

VII-confidentiality.

Sole Paragraph - No-one shall be obliged to be submitted to a mediation procedure.

Art. 3. Only conflicts addressing an issue that admits a settlement may be the subject of mediation.

$1^{s t}$ Paragraph - The mediation may address the whole conflict or part thereof.

$2^{\text {nd }}$ Paragraph - Agreements involving inalienable and non-negotiable rights must be ratified in court, requiring a consultation to the Public Prosecutor's Office when the interests of parties without legal capacity are involved.

$3^{\text {rd }}$ Paragraph-Disputes will not be submitted to mediation if they deal with:

I - filiation, adoption, paternal power, and/or annulment of matrimony;

II - restraint; 
III - judicial recovery and bankruptcy;

Section II - The Mediators

Subsection I-Common Provisions

Art. 4. The mediator will be chosen by the parties or, if hel/she is appointed, shall be accepted by them.

$1^{\text {st }}$ Paragraph -The mediator will conduct the process of communication between the parties, seeking understanding and consensus and easing resolution of the conflict by agreement.

$2^{\text {nd }}$ Paragraph - In the performance of his/her function, the mediator will proceed with impartiality, independence and discretion.

Art. 5. The same legal hypotheses of impediment and partiality of judges apply to the mediator.

Art. 6. The mediator will be prevented from advising, representing or acting for any party that was submitted to mediation conducted by him/her within the two preceding years.

Art. 7. Unless agreed upon otherwise, the mediator may not act as an arbitrator, nor function as a witness in arbitral or judicial proceedings pertinent to a conflict in which he/she acted as mediator.

Art. 8. The mediator and all those who advise him/ her in the mediation procedure, when exercising their functions or by virtue of them, are held equivalent to a public servant, for purposes of criminal legislation.

\section{Subsection II - Out-of-Court Mediators}

Art. 9. Any capable person, enjoying the trust of the parties and who considers him/herself qualified to perform mediation may function as a mediator, without regard to membership in any type of council or association or being registered therein. 
Art. 10. A capable person, graduated more than two years ago from a course of higher education at an institution recognized by the Ministry of Education and who has achieved qualification at a school or entity for training mediators, recognized by the National Council of Justice or the National School of Mediation and Conciliation at the Ministry of Justice, may act as a judicial mediator.

$1^{\text {st }}$ Paragraph - The courts will maintain updated registries of mediators qualified and authorized to act in judicial mediation.

$2^{\text {nd }}$ Paragraph - Registry in the register of judicial mediators will be requested by the interested party from the court with jurisdiction over the area in which he/she intends to exercise mediation.

$3^{\text {rd }}$ Paragraph - A mediator will be compulsorily excluded from the register if he/she:

I-violates the principles set forth in this Law;

II - acts in a mediation procedure, in the event of impediment or partiality;

III - is definitively convicted as a result of a criminal proceeding or one of administrative malfeasance.

$4^{\text {th }}$ Paragraph - In the cases of sub-items I and II or the $3^{\text {rd }}$ paragraph, the disciplinary procedure for exclusion from the register of mediators will be conducted and judged before the court under whose jurisdiction the infringement occurred, with the right of access to the adversarial system assured.

$5^{\text {th }}$ Paragraph - The court shall inform the name of mediators who are excluded from its register to the National Council of Justice, which will forward such information to the other courts, for them to effect immediate exclusion, with no need for a disciplinary procedure. 
$6^{\text {th }}$ Paragraph - A mediator who is compulsorily excluded from the register of mediators of a court will no longer be admitted in any other.

Art. 11. The remuneration due to judicial mediators will be set by the courts and will be borne by the parties.

Sole Paragraph $-A$ waiver of costs in relation to a party who alleges poverty in court will require acceptance from the mediator.

Section III - The Mediation Procedure

\section{Subsection I - Common Provisions}

Art. 12. A person appointed to function as mediator shall communicate to the parties any fact or circumstance that may raise a doubt in relation to his/her impartiality to mediate the conflict, at which time he/she may be refused by either of them.

Art. 13. At the start of the first mediation meeting, and whenever he/she deems it necessary, the mediator shall advise the parties of the rules of confidentiality applicable to the procedure.

Art. 14. At the request of the parties or the mediator, with their consent, other mediators may be admitted to function in the same procedure, when this is advisable by virtue of the nature and complexity of the dispute.

Art. 15. Even if there is a judicial or arbitral proceeding in progress, the parties may submit themselves to mediation, in which case they will ask the judge or arbitrator to suspend the proceeding for a period sufficient for a consensual solution to the dispute.

$1^{\text {st }}$ Paragraph - The decision to suspend the proceeding in the terms requested by mutual agreement of the parties allows for no appeal. 
$2^{\text {nd }}$ Paragraph - Suspension of the proceeding does not prevent the granting of urgent measures by the judge or arbitrator.

Art. 16. The parties may be assisted by counsel.

Sole Paragraph -Ifjust one of the parties is assisted by a legal professional, the others may request the appointment of an ad hoc defender.

Art. 17. Mediation is deemed instituted on the date on which its initial terms are signed.

$1^{\text {st }}$ Paragraph - The initial terms of mediation shall contain:

I - the qualification of the parties, and their attorneys, if any;

II - the name, profession and domicile of the mediator or mediators, and also, as the case may be, identification of the entity to which the parties delegated the appointment of mediators;

III - the description of the dispute submitted to mediation;

IV - a statement of responsibility for the payment of expenses with the mediation and the fees of the mediator, irrespective of whether a consensus is reached;

$V$ - place, date, and signature of the mediator, the parties and their attorneys, if any.

$2^{\text {nd }}$ Paragraph - The parties may include in the initial terms of mediation other matters they may deem pertinent, including the limits of the duty of confidentiality applicable to all those involved in the procedure, and signatories of the initial terms of mediation.

$3^{\text {rd }}$ Paragraph - While the mediation procedure is in progress, the statute of limitations will be suspended 
as from signature of the initial terms.

Art. 18. Once mediation is instituted, subsequent meetings attended by the parties may only be scheduled with their consent.

Art. 19. In the performance of his/her function, the mediator may meet with the parties, together or separately, hear third parties and ask the parties for information deemed necessary to clarify the facts and facilitate understanding between the parties.

Art. 20. The mediation procedure will be closed, drawing up its final terms, when an agreement is reached or when new efforts to obtain a consensus are not justified, either by a statement from the mediator in this regard or through a statement from either of the parties.

$1^{\text {st }}$ Paragraph - The final terms of mediation shall contain:

I-the qualification of the parties and their attorneys and representatives, if any;

II - a summary of the dispute;

III - the description of the agreement, with the rights and obligations of each party, or a statement or declaration that it is no longer possible to obtain a consensual resolution;

IV-place, date, signature of the mediator and, if an agreement has been reached, the signatures of the parties and their attorneys, if any.

$2^{\text {nd }}$ Paragraph -The final terms of mediation constitute an out-of-court title to execution and, when ratified in court, a judicial title to execution.

Subsection II-Out-of-Court Mediation

Art. 21. The invitation to start the procedure of outof-court mediation may be made by any means of 
communication.

Sole Paragraph - The invitation made by one party to another will be deemed rejected if not replied to in the timeframe stipulated in their contract if any, or in its absence, within thirty days from the date of its receipt.

Art. 22. If there is no stipulation addressing the procedure, the mediator shall establish one, taking into account the circumstances of the case, the interests expressed by the parties and the need for a speedy resolution to the dispute..

Art. 23. If, in the initial terms of mediation, the parties undertake not to begin an arbitration proceeding or lawsuit for a certain period or until implementation of a certain condition, the arbitrator or the judge will suspend the course of the arbitration or lawsuit for the period previously agreed upon or until implementation of that condition.

Sole Paragraph - The provisions of the main section of this article do not apply to urgent measures in which access to the Judiciary Branch is necessary to avoid the extinction of a right.

Subsection III - Judicial Mediation

Art. 24. In judicial mediation, the mediators will be appointed by distribution and submitted to the acceptance of the parties.

Art. 25. If the judge, on receipt of the initial petition, should verify that the controversy is suited to a resolution by means of mediation, he/she will forward the case to the judicial mediator, appointed by distribution, unless the petition is accompanied by a statement in which the plaintiff states his refusal to participate in the procedure.

$1^{\text {st }}$ Paragraph - On receiving the case file, the mediator will request the parties, by any means of communication, to make a statement within fifteen 
days on their willingness to submit to the procedure and their acceptance of the mediator appointed.

$2^{\text {nd }}$ Paragraph - If there is no answer from either of the parties, the mediation procedure will be deemed rejected, and the mediator shall forthwith return the case file to the judge, for him to proceed with the case.

$3^{r d}$ Paragraph - If the parties decide to submit themselves to mediation and the mediator is accepted, he/she will schedule the initial session of mediation, on a day and time previously agreed on, respecting the timeframe of thirty days.

$4^{\text {th }}$ Paragraph - If the procedure is accepted, but the mediator rejected, the latter shall communicate forthwith to the registry office or court secretariat, which will redistribute the case records to another mediator.

Art. 26. The judicial mediation procedure shall be concluded within sixty days, counting from the first session, unless the parties, by mutual agreement, request its extension.

$1^{\text {st }}$ Paragraph - If the mediation is concluded without an agreement being reached, the initial and final terms of mediation will be forwarded to the judge, who will proceed with the case.

$2^{\text {nd }}$ Paragraph - If there is an agreement, the records will be forwarded to the judge, who will order closure of the initial petition and, provided this is requested by the parties, will ratify, through a nonappealable ruling, the final terms of the mediation.

Art. 27. If the dispute is resolved by mediation before the defendant is cited, final court costs will not be due.

Section IV-Confidentiality and its Exceptions

Art. 28. All and any information concerning the 
mediation procedure shall be confidential in relation to third parties, and may not be revealed, even in an arbitral or court proceeding, unless the parties expressly decide otherwise or when its disclosure is required by law or necessary for implementation of the agreement obtained by mediation.

${ }^{\text {st }}$ Paragraph - The duty of confidentiality applies to the mediator, the parties, their representatives, counsel, technical advisors and other persons in their trust who directly or indirectly took part in the mediation procedure, encompassing.

I - a statement, opinion, suggestion, promise or proposal made by one party to the other in the search for understanding in the conflict;

II - recognition of a fact by either of the parties in the course of the mediation procedure;

III - a statement of acceptance of a proposal for agreement presented by the mediator;

$I V$ - a document prepared solely for purposes of the mediation procedure.

$2^{\text {nd }}$ Paragraph - Evidence submitted which is noncompliant with this article will not be admitted in a judicial or arbitral proceeding.

$3^{\text {rd }}$ Paragraph - The rule of confidentiality will not cover information concerning the occurrence of a criminal action.

Art. 29. Information furnished by a party in a private session will be confidential, and the mediator may not reveal it to the others, unless expressly authorized.

Chapter II

The Settlement of Disputes to which a Public-law Legal Entity is Party 
Section I-Common Provisions

Art. 30. The Federal Union, States, the Federal District and Municipalities may create chambers for the administrative prevention and resolution of disputes, with competency to:

I- settle conflicts between entities and bodies of the public administration;

II -appraise the admissibility of requests for resolution of disputes, by means of settlement, in the case of controversy between a private party and a public-law legal entity.

III - promote, when fitting, execution of an undertaking of adjustment of conduct.

$1^{\text {st }}$ Paragraph - The mode of settlement and functioning of the chambers addressed in the main section will be established in regulations by each entity of the federation.

$2^{\text {nd }}$ Paragraph -Submission of a conflict to the chambers addressed in the main section is optional and will be fitting only in the cases addressed in the regulations of the respective entity of the federation.

$3^{\text {rd }}$ Paragraph - If there is a consensus between the parties, an agreement will be drawn up, and except in the case of sub-item I, will constitute an out-ofcourt title to execution.

$4^{\text {th }}$ Paragraph - Not included in the competency of the bodies mentioned in the main section of this article are controversies that can only be resolved by acts or concession of rights subject to authorization from the Legislative Branch or which may entail excessive burdens for the Public Administration.

$5^{\text {th }}$ Paragraph - The provisions of sub-items II and III of the main section do not apply to legal controversies in taxation matters. 
Art. 31. Opening an administrative proceeding for the consensual resolution of a conflict within the realm of the Public Administration suspends the statute of limitations.

$1^{s t}$ Paragraph - The procedure is deemed opened when the public entity or body issues a positive judgment of admissibility, with suspension of the statute of limitations retroactive to the date of formalizing the request for consensual resolution of the conflict.

$2^{\text {nd }}$ Paragraph - In cases of taxation matters, suspension of the statute of limitations shall observe the provisions of Law No. 5,172, of October 251966 - National Taxation Code.

Section II -Conflicts Involving the Direct Federal Public Administration, its Autarkies and Foundations

Art. 32. The solution of legal controversies that involve the direct Federal Public Administration, its autarkies and foundations, may be addressed in settlement by adhesion, based upon:

I-authorization from the Federal Attorney-General, based on unanimous case law at the higher courts or the Federal Supreme Court; or

II - an opinion from the Federal Attorney-General, approved by the President of the Republic.

$1^{\text {st }}$ Paragraph - The requirements and conditions of settlement by adhesion will be defined in a specific administrative resolution.

$2^{\text {nd }}$ Paragraph - When making the request for adhesion, the interested party shall attach proof of meeting the requirements and conditions established in an administrative resolution.

$3^{\text {rd }}$ Paragraph - The administrative resolution will have general effects and will be applied to identical 
cases, timely qualified by a request for adhesion, albeit to resolve only part of the controversy.

$4^{\text {th }}$ Paragraph - Adhesion will imply the interested party's waiving the right that underpins any lawsuit or appeal that may be pending, either administrative or judicial, with regard to the points encompassed by the subject of the administrative resolution.

$5^{\text {th }}$ Paragraph - If the interested party is party to a lawsuit opened through a class action, waiver of the right that underpins the lawsuit shall be express, by means of a petition addressed to the judge of the case.

$6^{\text {th }}$ Paragraph - Formalization of an administrative resolution destined to settlement by adhesion does not entail tacit waiver of the statute of limitations, nor its interruption or suspension.

Art. 33. In the case of disputes that involve a legal controversy between public-law entities or bodies that make up the Federal Public Administration, the Federal Attorney-General's Department shall effect the out-of-court settlement of the conflict, observing the procedures laid down in an act of the Federal Attorney-General.

$1^{\text {st }}$ Paragraph - In the hypothesis addressed in the main section, if there is no agreement on the legal controversy, it will fall to the Federal AttorneyGeneral to settle it, based on the legislation.

$2^{\text {nd }}$ Paragraph - In cases in which resolution of the controversy implies recognition of the existence of credits of the Federal Union, its autarkies or foundations, against federal public-law legal entities, the Federal Attorney-General's Department will ask the Ministry of Planning, Budget and Management for a budget adaptation to settle the debts recognized as legitimate.

$3^{\text {rd }}$ Paragraph - Out-of-court settlement of the conflict does not rule out identifying responsibility 
of the public agent who gave rise to the debt, whenever it is found that his/her action or omission constitutes, in theory, a disciplinary infringement.

$4^{\text {th }}$ Paragraph - In cases in which the matter addressed in the dispute is being discussed in an action of administrative malfeasance, or on which there is a decision from the Federal Court of Accounts, the conciliation addressed in the main section will depend on the express consent of the judge of the case or the reporting Justice.

Art. 34. The States, Federal District and Municipalities, their public foundations and autarkies, along with federal public companies and mixed-capital corporations, may submit their disputes with entities or bodies of the Federal Public Administration to the Federal AttorneyGeneral's Department, for purposes of settling the conflict out of court.

Art. 35. In cases in which the legal controversy is related to taxes administrated by the Federal Revenue Secretariat of Brazil or to credits entered as Federal debts subject to execution:

I-the provisions of sub-items II and III of the main section of art. 30 do not apply;

II - public companies, mixed-capital corporations and their subsidiaries that exploit an economic activity of production or commercialization of goods or the provision of services, may not exercise the option addressed in art. 34;

III - when the parties referred to in the main section of art. 33 are parties:

a) submission of the conflict to out-of-court settlement by the Federal Attorney-General's Department implies waiving the right to appeal to the Administrative Council of Taxation Appeals;

b) reduction or cancellation of the credit will depend 
on a joint statement from the Federal AttorneyGeneral and the Minister of State for Finance.

Art. 36. Filing a lawsuit in which appear as plaintiffs or defendants Federal public-law entities or bodies, shall be authorized in advance by the Federal Attorney-General.

Sole Paragraph - The competency addressed in the main section may be delegated.

Art. 37. Public servants and employees who participate in the process of out-of-court settlement of the dispute may only be liable in the civil, administrative or criminal spheres when, through malice or fraud, they receive any undue financial advantage, allow or ease its reception by a third party, or contribute to this end.

Chapter III Final Provisions

Art. 38. The entities and bodies of the Public Administration may create chambers for the resolution of conflicts between private parties, which involve activities regulated or supervised by them.

Art. 39. Arts. 1 and 2 of Law No. 9,469, of July 10 1997, shall henceforth be in effect with the following wording:

"Art. 1. The Federal Attorney-General, directly or through delegation, and the highest-level directors of federal public companies, jointly with the statutory director of the area affected by the matter, may authorize reaching agreements in settlements to prevent or terminate a dispute, including judicial disputes.

$1^{\text {st }}$ Paragraph - Specialized chambers may be created, made up of public servants or effective public employees, with the aim of analyzing and formulating proposals for agreements or settlements. 
$2^{\text {nd }}$ Paragraph - Regulations will address the form of composition of the chambers addressed in the $1^{\text {st }}$ paragraph, which shall have as a member at least one full member of the Federal Attorney-General's Department, or, in the case of public companies, a legal assistant or occupant of an equivalent function.

$3^{\text {rd }}$ Paragraph - When the dispute involves amounts above those set in the regulations, the agreement or settlement, on pain of nullity, will require prior and express authorization from the Federal AttorneyGeneral or the Minister of State or head of the Secretariat of the Presidency of the Republic and whose area of competency is pertinent to the matter, or also the Speaker of the House of Representatives, the Federal Senate, the President of the Federal Court of Accounts, of a Court or Council, or the Federal Chief Prosecutor, in the case of interests of the Legislative and Judiciary Branches, or of the Federal Public Prosecutor's Department, excluding non-dependent public companies, which will require only the prior and express authorization of the directors referred to in the main section.

$4^{\text {th }}$ Paragraph - In a settlement or agreement reached directly by the party or through the mediation of an attorney to extinguish or close a legal proceeding, or also in cases of administrative extension of payments pursued in court, the parties may define the responsibility of each one of them for the payment of the fees of their respective counsel." [New Wording].

"Art. 2. The Federal Attorney General, the Federal Chief Prosecutor, the Attorney-General of the Central Bank of Brazil and the directors of the federal public companies mentioned in the main section of art. 1 may authorize, directly or through delegation, reaching agreements to prevent or terminate, in or out of court, a dispute that involves amounts below those set in the regulations.

$1^{\text {st }}$ Paragraph - In the case of federal public companies, delegation is restricted to a formally- 
constituted joint board, consisting of at least one statutory officer.

$2^{\text {nd }}$ Paragraph - The agreements addressed in the main section may consist of payment of the debit in monthly and successive instalments, up to a maximum of 60 (sixty).

$3^{\text {rd }}$ Paragraph - The amount of each monthly instalment, at the time of payment, will undergo the addition of interest equivalent to the reference rate of the Special System of Clearing and Custody - SELIC for federal securities, accumulated monthly, calculated from the month following that of consolidation until the month preceding that of payment, and of $1 \%$ (one per cent) relative to the month in which the payment is being made.

$4^{\text {th }}$ Paragraph - In the event of default on any instalment, after thirty days, an execution proceeding will be opened or continued, for the balance." [New Wording]

Art. 40. Decree No. 70,235, dated March 06 1972, shall henceforth be in effect with addition of the following provision:

"Art. 14-A. In the event of determination and requirement of Federal Union tax credits whose debtor is a public-law entity or body of the Federal Public Administration, submission of the dispute to out-of-court settlement by the Federal AttorneyGeneral's Department is considered a claim for the purposes of the provision of art. 151, III, of Law No. 5,172, of October 251966 - National Taxation Code."

Art. 41. This Law applies, insofar as fitting, to other consensual forms of conflict resolution, such as community, school, criminal and labor mediations, and also those put into effect at out-of-court offices.

Art. 42. Mediation may be done on the internet or by any other means of communication that allows 
remote transmission, provided that the parties are in agreement.

Sole Paragraph - A party domiciled abroad may participate in mediation according to the rules established in this Law.

Art. 43. This Law comes into effect one hundred and eighty days after its publication.

Art. 44. The $2^{\text {nd }}$ paragraph of art. 6 of Law No. 9,469, of July 10 1997, is revoked.

Commission Office

Chairman

Reporter

This text, on reaching the House, will probably be attached to PL 94/02, which has now been under way for over fifteen years (former PL 4827/98), with no significant evolution. We imagine that a new Substitute will be presented which, once voted, will have to go back to the Senate.

\section{OUTLOOK FOR BRAZILIAN LAW}

Even though this paper has concentrated on the procedural issues pertaining to mediation, we hold the opinion that the best model is the one which urges the parties to seek a consensual resolution, making every effort before filing a lawsuit. A resolution extolling only a system of very well-equipped incidental mediation mechanisms after a lawsuit has already been initiated does not appear to be ideal, as the judicial machinery will already be in motion, when, in many cases, this could have been avoided ${ }^{10}$.

On the other hand, we do not agree with the idea of obligatory mediation or conciliation. The voluntary nature is the essence of such procedures. This feature can never be compromised, even with the argument that it is a form of educating the people and implementing a new form of public policy.

10 PINHO, Humberto Dalla Bernardina de. PAUMGARTTEN, Michele Pedrosa. A experiência ítalo-brasileira no uso da mediação em resposta à crise do monopólio estatal de solução de conflitos e a garantia do acesso à justiça, in Revista Eletrônica de Direito Processual, volume 8 , available at http://www.redp.com.br. 
However, we are forced to acknowledge that, in certain cases, mediation and conciliation must be regulatory stages of the procedure, to the extent that such tools prove to be the best suited to the outcome of that particular dispute.

Thinking of a prior and obligatory instance of conciliation, in cases in which only property issues are being discussed, or imposing sanctions for not accepting a reasonable settlement (such as payment of the costs of the proceeding or the attorneys' fees, even if the party is successful, when that amount is exactly what was decided by the judge in the decision), may be valid solutions. They are examples from English law ${ }^{11}$ and U.S. law ${ }^{12}$, which deserve to be studied.

But should never be applied in a mediation where there are profound emotional issues - quite often unconscious - that require time, maturity and mutual trust to be exposed and resolved ${ }^{13}$.

However, we are obliged to acknowledge that it is necessary to seek a resolution for cases in which mediation is the most suitable solution, yet rejected by the parties for no plausible reason.

The Judiciary cannot be allowed to be used, abused or manipulated at the whim of litigants who quite simply want to fight or push the dispute to new frontiers.

We reassert here our opinion that the parties should have the obligation to demonstrate to the Court that they have tried, in some way, to seek a consensual resolution for the dispute..

We support, as already stated $^{14}$, expanding the procedural concept of interest to act, welcoming the idea of adaptation, within the binomial need-usefulness, as a way to rationalize the measure of jurisdiction and avoid unnecessary resort to the Judiciary Branch, or even abuse of the right of action.

This view may lead to a difficulty of harmony with the principle that jurisdiction may not be delegated; that the judge may not evade his

11 ANDREWS, Neil. The Three Paths of Justice. Cambridge: Springer, 2012, p. 197

12 As an example, we may mention Rule 68 of the F.R.C.P.: "Federal Rules of Civil Procedure. Rule 68. OFFER OF JUDGMENT. (a) MAKING AN OFFER; JUDGMENT ON AN ACCEPTED OFFER. At least 14 days before the date set for trial, a party defending against a claim may serve on an opposing party an offer to allow judgment on specified terms, with the costs then accrued. If, within 14 days after being served, the opposing party serves written notice accepting the offer, either party may then file the offer and notice of acceptance, plus proof of service. The clerk must then enter judgment. (...)". Text available athttp://www.uscourts.gov, access on Sep. 122013.

13 PINHO, Humberto Dalla Bernardina de. PAUMGARTTEN, Michele Pedrosa. Os efeitos colaterais da crescente tendência à judicialização da mediação, in Revista Eletrônica de Direito Processual, volume 10, Jan-Jun. 2013.

14 PINHO, Humberto Dalla Bernardina de Pinho. A Mediação e a necessidade de sua sistematização no processo civil brasileiro, in REDP -YEAR $4-5^{\text {th }}$ volume - January - June 2010, available at http://www.redp.com.br, p. 147. 
function of judging, that is to say, if a citizen knocks at the door of the Judiciary, his access shall not be denied or hindered, pursuant to article 5, sub-item XXXV of the 1988 Constitution.

What must be clarified is the fact that a party under jurisdiction requesting measures from the state does not mean that the Judiciary must, always and necessarily, offer a response of imposition, doing no more than applying the law to the case in point ${ }^{15}$.It may be that the judge understands that those parties must be submitted to a conciliatory, pacifying stage, before any technical decision should be issued ${ }^{16}$.

This is made very clear in the legislative bill for the new CPC, to the extent that art. 139 grants the judge a whole series of powers, especially with regard to steering the proceeding, expressly mentioning adaptation and mitigated flexibility as tools for attaining effectiveness.

On this point, obviously the judge's paramount concern will be with the actual pacification of that dispute, rather than with merely rendering a judgment, as a form of technical-juridical answer at the urging of the party under jurisdiction.

If the new CPC requires from the judge absolute fidelity to the Constitutional Principles, converting him/her, beyond question, into an agent of preservation of the constitutional guarantees, on the other hand, it also grants him/her with instruments to acquire profound knowledge of the conflict, encompassing its reasons, albeit-meta-legal, so to as to effect its pacification.

In this regard, it is necessary to establish a system balanced between judicial and out-of-court mediation, so as to firmly guarantee access to justice and maintain a Judiciary that is agile, speedy and effective. Once a lawsuit has been filed, just as we have developed a system of filters for repetitive cases, we also have to think of a multidoor system that adapts to each type of dispute.

Another point that strikes me as vital is the construction of a collaborative network ${ }^{17}$, involving the entities of the Judiciary Branch and sectors of organized civil society possessing the structure necessary to offer this service under a regime of cooperation. I am referring to out-of-court registry offices, the public and private universities, professional associations, the Public Defenders and Prosecutors, and

15 MANCUSO, Rodolfo de Camargo. A resolução dos conflitos e a função judicial no Contemporâneo Estado de Direito.São Paulo: Revista dos Tribunais, 2009.

16 PINHO, Humberto Dalla Bernardina de. Mediação: a redescoberta de um velho aliado na solução de conflitos, in: Acesso à Justiça: efetividade do processo (org. Geraldo Prado). Rio de Janeiro: Lumen Juris, 2005, pp. 105/124.

17 SPENGLER, Fabiana Marion; SPENGLER NETO, Theobaldo.Mediação enquanto politica pública: a teoria, a prática e o projeto de lei. Santa Cruz do Sul, Edunisc, 2010. http://www. unisc.br/portal/pt/editora/e-books/95/mediacao-enquanto-politica-publica-a-teoria-a-pratica-eo-projeto-de-lei-.html. 
Public Advocacy.

Thinking of judicial mediation alone will not resolve the problem of the overload of work that currently presses down on the judges' shoulders. On the contrary, it will most likely cause a new "boom" of cases, just as happened with enactment of the CDC (Consumer Defense Code) in 1990 and institution of the Civil Special Courts, in 1995.

Faced with this, we are obliged to recognize that, before enacting our future law of mediation, we have to build this network and prepare it for the volume of cases to come, in order to avoid the risk of compromising this institution before it even comes into effect.

\section{REFERENCES}

ANDREWS, Neil. (trad. Teresa Alvim Arruda Wambier). O Moderno Processo Civil: formas judiciais e alternativas de resolução de conflitos na Inglaterra, São Paulo: Revista dos Tribunais, 2009.

BESSO, Chiara. La Mediazione Italiana: Definizioni e Tipologie. Artigo disponível no vol. VI da Revista Eletrônica de Direito Processual, disponível no endereço http://www.redp.com.br, acesso em 10 de janeiro de 2011.

COMOGLIO, Luigi Paolo. Mezzi Alternativi de Tutela e Garanzie Costituzionali, in Revista de Processo, vol 99, p. 249/293.

FULLER, Lon. Mediation. Its Forms and Functions, CAL. L. REV vol. 305, 1971.

MANCUSO, Rodolfo de Camargo. A resolução dos conflitos e a função judicial no Contemporâneo Estado de Direito. São Paulo: Revista dos Tribunais, 2009.

MIRIMANOFF Jean A., Une nouvelle culture : la gestion des conflits, in: APJ/PJA, février 2009, www.gemme.ch.

MUÑOZ, Helena S.. La mediación: método de resolución alternativa de conflictos en el proceso español. Revista Eletrônica de Direito Processual Civil. vol. III, p. 66-88, jan-jun. 2009.

NOLAN-HALEY, Jacqueline M. The Merger of Law and Mediation: Lessons from Equity Jurisprudence and Roscoe Pound. Cardozo Journal of Dispute Resolution, vol. 6, 2004.

OWEN, Fiss. Alternative Dispute Resolutions Debated: Second-Hand Justice? The Connecticut Law Tribune. March 17, 1986.

PELUSO,Antonio Cezar. RICHA, Morgana deAlmeida [coordenadores]. Conciliação e Mediação: estruturação da política judiciaria nacional, Rio de Janeiro: Forense, 2011.

PINHO, Humberto Dalla Bernardina de [organizador]. Teoria Geral da Mediação à luz do Projeto de Lei e do Direito Comparado, Rio de Janeiro: Lumen Juris, 2008.

PINHO, Humberto Dalla Bernardina de Pinho. A Mediação e a 
necessidade de sua sistematização no processo civil brasileiro, in REDP - ANO 4 - $5^{\circ}$ volume - Janeiro a Junho de 2010, disponível em http://www.redp.com.br.

PINHO, Humberto Dalla Bernardina de Pinho. DURCO, Karol. A Mediação e a Solução dos Conflitos no Estado Democrático de Direito. O "Juiz Hermes" e a Nova Dimensão da Função Jurisdicional, disponível em http://www.humbertodalla.pro.br.

PINHO, Humberto Dalla Bernardina de. Mediação: a redescoberta de um velho aliado na solução de conflitos, in: Acesso à Justiça: efetividade do processo (org. Geraldo Prado). Rio de Janeiro: Lumen Juris, 2005. PINHO, Humberto Dalla Bernardina de. PAUMGARTTEN, Michele Pedrosa. A experiência ítalo-brasileira no uso da mediação em resposta à crise do monopólio estatal de solução de conflitos e a garantia do acesso à justiça, in Revista Eletrônica de Direito Processual, volume 8, disponível em http://www.redp.com.br.

PINHO, Humberto Dalla Bernardina de. PAUMGARTTEN, Michele Pedrosa. Os efeitos colaterais da crescente tendência à judicialização da mediação, in Revista Eletrônica de Direito Processual, voume 10, jan-jun 2013.

PINHO, Humberto Dalla Bernardina de.PAUMGARTTEN, Michele Pedrosa. Mediación Obligatoria: una versión moderna del autoritarismo procesal. Revista Eletrônica de Direito Processual. texto disponível em http://www.redp.com.br, vol.10, p.210 - 225, 2012

SPENGLER, Fabiana Marion; SPENGLER NETO, Theobaldo. Mediação enquanto política pública: a teoria, a prática e o projeto de lei. Santa Cruz do Sul, Edunisc, 2010. http://www.unisc.br/portal/ pt/editora/e-books/95/mediacao-enquanto-politica-publica-a-teoria-apratica-e-o-projeto-de-lei-.html. 